\title{
DO AMBIENTE TEÓRICO AO LABORATÓRIO PRÁTICO DO CAOS: PROFISSÃO MÉDICA E GUERRA DO PARAGUAI (1850 e 1860)
}

\author{
FROM THEORETICAL SCHOOLS TO THE CHAOTIC PRACTICAL \\ LABORATORY: MEDICAL PROFESSION AND PARAGUAYAN WAR \\ (1850S-1860S)
}

Vanessa de Jesus Queiroz ${ }^{1}$

\begin{abstract}
RESUMO: Este artigo investiga profissão médica no Brasil entre as décadas de 1850 e 1860, com ênfase nas transformações e dilemas apresentados aos médicos diplomados durante a Guerra do Paraguai. Com base na análise de decretos e outros escritos produzidos no período aqui elencado, buscamos perceber possibilidades de atuação desses esculápios, partindo da hipótese de que o confronto foi momento especial que evidenciou alguns obstáculos à luta por reconhecimento e exclusividade profissional, mas também foi palco de intensificação dos argumentos em defesa dos doutores certificados. A ameaça da cólera-morbo recebe centralidade em nosso texto, que está estruturado em três eixos principais, que versam sobre a medicina como saber institucionalizado no pré-guerra, a profissão e o mal colérico durante o conflito e breves reflexões sobre o conceito de classe médica.
\end{abstract}

PALAVRAS-CHAVE: Profissão médica, Médicos Diplomados, Guerra do Paraguai, Cólera-Morbo

ABSTRACT: This article investigates the medical profession in Brazil between the 1850s and 1860s, with an emphasis on the transformations and problems presented to professional doctors during the Paraguayan War. Based on the analysis of decrees and other documents produced in the period listed here, we seek to understand possibilities of professional action of physicians, starting from the hypothesis that the War was a special moment that evidenced some obstacles to the struggle for recognition and professional exclusivity, but it was also moment of intensifying arguments in defense of professional doctors. The threat of cholera-morbus is central in our text, which is structured in three main

\footnotetext{
* Este artigo decorre de uma pesquisa de doutorado em andamento no Programa de PósGraduação em História da Universidade de Brasília (PPGHIS-UnB). Ainda que não seja fruto de edital de financiamento específico, destaca-se que a autora, aluna da linha de História Social e suas múltiplas formas, é bolsista de pós-graduação do CNPq.

${ }^{1}$ Licenciada, bacharela, mestra e doutoranda da linha de História Social do Programa de Pós Graduação em História da Universidade de Brasília. Contato: vanessa_djq@ @otmail.com
} 
parts, in which we present the medicine as institutionalized knowledge before the War, the profession and cholera in the War and brief reflections about the historical concept of professional medical class.

KEYWORDS: Medical Profession, Graduate Doctors, Paraguayan War, Cholera-morbus

\section{Prolegômenos}

[...] Incumbiu-nos, ao morrer, de recomendar-lhe a família ao governo da patria [...] ainda depois de morto, como para continuar a intervenção benefica estendida sobre nós, a sua estancia do Jardim, que na agonia suprema os seus ultimos olhares puderam ainda entrever de uma para outra margem do rio, o seu laranjal que era o seu orgulho, de alguma fórma salvou-nos miraculosamente do cholera, pondo á nossa disposição os seus fructos innumeros, soccorro inesperado cujo valor suppunhamos pelo menos que elle exaggerasse, quando no-lo prometia[...] (TAUNAY, 1874, p.51-52)

As palavras acima dizem respeito a José Francisco Lopes, guia das tropas brasileiras durante a Retirada da Laguna, importante episódio da Guerra do Paraguai, narrado em uma das principais obras escritas por Alfredo Maria Adriano d'Escragnolle Taunay ${ }^{2}$, autor do trecho reproduzido. Nascido em Minas Gerais no ano de 1811, o guia de sobrenome homófono ao de um dos principais inimigos da nação brasileira ${ }^{3}$ possuía um bom conhecimento acerca de regiões fronteiriças e adjacências entre Brasil e Paraguai. Tal conhecimento adveio dos fatos de Lopes ter morado no Paraguai durante sete anos com sua família (TAUNAY, 1874, p.33) e de que residia e trabalhava na criação extensiva de gados numa fazenda em Mato Grosso do Sul, área de divisa entre o território brasileiro e o paraguaio.

Em 1865, numa incursão paraguaia ao Brasil, a esposa e os filhos de Lopes foram sequestrados. Após o ocorrido, o chefe de família, que conseguiu escapar, ofereceu seus serviços ao Exército brasileiro exercendo a função de guia. Sua contribuição foi de grande valia às tropas brasileiras, que contavam

\footnotetext{
${ }^{2}$ Rio de Janeiro, 1843-1899. Engenheiro militar, escritor, político, músico. Destacou-se por escrever obras como A Retirada da Laguna (1874), Dias de Guerra e de Sertão (1923, obra póstuma) e o romance Inocência (1872).

${ }^{3}$ Referimos-nos a Francisco Solano López.
} 
com engenheiros ${ }^{4}$ - e o próprio Taunay era membro da comissão de engenharia-, para o reconhecimento de terrenos e auxílio ao planejamento das táticas de batalha, mas não contavam com satisfatório conhecimento acerca dos territórios da campanha, sobretudo das terras inimigas. Sua competência, conforme aponta Taunay (1874, p.32), extrapolava o extenso conhecimento territorial, pois o guia "gostára de excursões longinquas desde a infancia", e era "sobrio em extremo (...)", de modo que podia "viajar dias inteiros sem beber".

Muitas interpretações sobre a Guerra do Paraguai são possíveis a partir do trecho escrito por Taunay sobre a participação de Lopes no conflito, a exemplo de reflexões sobre o chamado recrutamento voluntário ou sobre como a batalha afetou a vida de homens e mulheres comuns como ele, que teve sua família levada como prisioneira para o país inimigo ${ }^{5}$. Contudo, neste artigo nosso objetivo é discutir sentidos da profissão médica durante a Guerra do Paraguai, partindo da hipótese de que o momento belicoso é lugar importante para problematizar a figura do médico no Brasil oitocentista. Visto que são muitas as possibilidades de debate sobre tal problema, aqui preconizamos dois caminhos argumentativos. O primeiro é voltado a refletir sobre ensino e profissão médica no pré-guerra, com foco nos ambientes das faculdades de medicina do Império e da Junta Central de Higiene Pública. O segundo concentra-se em pensar atuação médica na conflagração, incluindo a cóleramorbo no que tange aos embates e dilemas que o enfrentamento da epidemia causava aos envolvidos, especialmente aos esculápios dentro e fora do campo de batalha. Adotando tal perspectiva, explicamos alguns porquês de o trecho de Taunay, que fala sobre um personagem não médico, nos ajudar a pensar sobre a relação entre médicos profissionais e o confronto.

Ponto fundamental está na citação da moléstia que ceifou Lopes e seu filho primogênito: a cólera-morbo. Nas narrativas de Taunay, nos mapas

\footnotetext{
${ }^{4}$ Conforme atestam fontes sobre o período, a exemplo da própria obra de Taunay que aqui utilizamos. Encontramos na página 45 a informação de que: "O batalhão n.21 recebeu de improviso ordem de escoltar os engenheiros a uma exploração dos sitios cirumvisinhos à colônia" (TAUNAY, 1874, p.45).

${ }^{5}$ Lopes conseguiu rever seu filho pouco tempo antes de morrer. O mesmo conseguiu escapar dos paraguaios.
} 
nosológicos e mortuários, nas imprensas médica e não médica, em relatórios ministeriais e diversos outros documentos produzidos durante a Guerra, as epidemias demonstram-se inimigas perigosas que matavam mais do que as armas de fogo. Na primeira parte de sua obra sobre a retirada da Laguna, além da cólera, Taunay menciona a varíola, as febres paludosas, a paralisia reflexa, as febres gerais e outros problemas, como as exaustões física e emocional. Todas as doenças eram agravadas pela fome, um mal muito presente, que tornava mais débeis e frágeis os corpos cansados dos combatentes ${ }^{6}$.

Taunay menciona uma certa continuidade de ação benéfica da parte de Lopes mesmo nos momentos de seu declínio. O guia, fundamental orientador geográfico que ajudou diversas vezes na aquisição de gado para alimentar as tropas em épocas de escassez, dispôs ao batalhão os frutos de seu laranjal. Afora combater a fome dos soldados, segundo o autor, os frutos salvaram-nos da cólera-morbo, confirmando a promessa de Lopes. Esta parte evidencia que sujeitos não diplomados nas artes médicas estavam cientes e tinham suas próprias apostas de combate à doença. Estas disputavam lugar com as terapêuticas propostas por esculápios diplomados que atuavam nas frentes de batalha. Acontecimentos como o da "cura pelos frutos do laranjal" fortaleciam outras formas de curar, propostas por não médicos, o que ora servia de objeto de análise e/ou aprendizado aos esculápios diplomados, ora podia dificultar a autoridade de suas indicações de tratamento contra a enfermidade, principalmente quando registradas em obras deveras valorizadas pelo Governo da nação com grande probabilidade de leitura entre classes da elite, como foi a de Taunay.

Apesar de o Brasil já ter vivido uma epidemia de cólera na década anterior, entre 1855-1856, não se sabia com plena certeza o que causava a moléstia, tampouco se tinha métodos de cura consensuais e efetivos para combatê-la. A confirmação da promessa de Lopes é exemplo de que saberes outros, que não os exclusivos das ciências médicas, tinham lugar importante

\footnotetext{
${ }^{6}$ É fundamental compreender que por mais que males como a fome e o cansaço tenham sido problemas a que todos estavam sujeitos na Guerra, a hierarquia tornava, por vezes, mais árduas as jornadas de soldados e baixas patentes em relação as de alguns oficiais e altas patentes.
} 
durante a Guerra do Paraguai. Os médicos diplomados conviviam com tais saberes.

Outra possibilidade reflexiva provinda do episódio do laranjal é que nem todos os casos que se pensava ser de cólera de fato o eram. Hoje em dia é conhecimento comum que a vitamina $\mathrm{C}$ e outras, presentes em frutas como a laranja, auxiliam no combate a enfermidades diversas. É factível ponderarmos que a ingestão dos frutos pode ter auxiliado na recuperação de outros tipos de distúrbios diagnosticados como cólera na época. Luiz de Castro Souza (1972, p. 87), por exemplo, afirma em suas reflexões que o que atacou uma força expedicionária de Mato Grosso durante a contenda não foi o mal colérico, como está registrado em uma série de fontes médicas da época, mas sim uma gastroenterite aguda ocasionada pelo mau estado do gado, seu cozimento inadequado e pelo consumo de partes indevidas do corpo animal. Toda a situação potencializada pelas demais dificuldades de salubridade enfrentadas pelas tropas.

Por fim, nos cabe a reflexão sobre o pedido de Lopes de ser reconhecido pelo Governo do Brasil. Ele carregava a esperança de que sua atuação no conflito lhe rendesse galardão para que o Estado o recompensasse com o cuidado aos seus familiares após sua morte. Trata-se da demonstração de esperanças que eram nutridas quando se decidia participar de uma guerra. A criação de expectativas, a despeito de que fossem outras, igualmente fazia parte das intenções dos médicos que participavam do combate, sobretudo no que diz respeito à detenção da atenção do Governo Imperial para as demandas propostas por estes profissionais.

O relato de Taunay é um, dentre os diversos documentos sobre a Guerra, que contam com a presença das doenças como objetos fundamentais de análises sobre o confronto. Estas podiam causar estragos no teatro da contenda e invadir o território brasileiro por meio de navios provindos da batalha. Assim, as enfermidades eram questão de interesse de diversos grupos.

Com base em uma metodologia de análise conjunta de diversos documentos escritos - jornais, relatórios dos ministérios dos Negócios da 
Guerra e do Império, correspondências e relatos em livro-, produzidos por diferentes agentes - médicos, ministros, entre outros-, este artigo é dividido em três partes.

$\mathrm{Na}$ primeira, traçamos um panorama sobre formação e atuação de médicos profissionais no Brasil da década anterior à Guerra. Nesta parte, que preconiza os ambientes institucionais das faculdades de medicina do Império $^{7} \mathrm{e}$ a Junta Central de Higiene Pública, o objetivo é demonstrar como algumas fragilidades do ensino oficial e estrutura institucional, incluindo a de fiscalização e vigilância, são imprescindíveis para pensar atuação médica na Guerra, uma vez que parte de nosso argumento central considera o momento bélico em questão especialmente profícuo para pensar sobre a figura do médico profissional. Trata-se de focalizar a atuação de esculápios na transição de um momento de paz para um momento de caos, de problematizar como o ensino e a estrutura institucional do saber médico oficial produzido nas faculdades afetaram a presença destes sujeitos no conflito. Investigar os certificados por escolas de medicina envolve a consideração daqueles que não pertenciam a tais ambientes. O conflito entre diplomados e não-diplomados ocorreu antes, durante e após o confronto, sendo, portanto, ponto de interesse de nossa análise.

$\mathrm{Na}$ segunda, nos preocupamos com atuação médica na Guerra, com destaque para a presença da cólera-morbo como moléstia chave para melhor compreender a dimensão dos serviços médicos no campo de batalha. Como veremos, a doença foi um dos cernes da disputa por autoridade entre médicos profissionais alopatas e outros indivíduos que participavam do confronto. Dialogamos com parte da historiografia brasileira sobre a ocorrência da mazela na década de 1850 para melhor entender os efeitos de suas aparições na década de 1860 .

$\mathrm{Na}$ terceira, as considerações finais, fazemos uma breve reflexão acerca das diferenças entre as categorias de médico civil e médico militar no intuito de

\footnotetext{
${ }^{7}$ Aqui não é trivial alertarmos que a Guerra do Paraguai é um tema muito estudado por pesquisadoras e pesquisadores de diversos países. Assim sendo, justificamos que a escolha por preconizar as Faculdades de Medicina do Rio de Janeiro e da Bahia diz respeito a serem as únicas escolas de medicina com que contava o Império no recorte temporal que elegemos- as décadas de 1850 e 1860.
} 
pensar sobre a pluralidade contida no conceito de classe médica. Discutimos possibilidades e limites de tal categoria histórica.

Formação e atuação médicas nas faculdades de medicina do Império e a Junta Central de Higiene Pública no pré-Guerra

Em 1854, com o Decreto n. 1.387 de 28 de abril, rubricado pelo imperador e assinado por Luiz Pedreira do Couto Ferraz, ministro e secretário dos Negócios do Império, as faculdades de medicina do Brasil ganhavam seus estatutos. $\mathrm{O}$ ano deste regulamento contou com diversas outras mudanças que ocorreram em estabelecimentos de ensino da Corte, não só no nível superior, mas também no primário e no secundário.

Sucessores da Lei de 03 de outubro de 1832, que em seus 35 artigos transformou as academias médico-cirúrgicas do Rio de Janeiro e da Bahia em faculdades de medicina e deu outras disposições, os 204 artigos do decreto de 1854 criavam e/ou reformulavam regras e instruções acerca de diversos pontos institucionais das faculdades de medicina do Império. A regulação de 1854 apresentou às escolas médicas uma série de mudanças que iam desde a organização do pessoal até a inserção de cadeiras e matérias, a exemplo de química orgânica e patologia geral, nos currículos dos cursos de medicina, farmácia e partos.

A previsão de fundação de laboratórios para auxílio ao ensino de química, física, história natural, anatomia, horto botânico e outras áreas, era uma novidade do decreto 1.387, que concretizava a divisão do curso médico em três seções (ciências acessórias, ciências cirúrgicas e ciências médicas), definia a duração do curso de partos (2 anos), previa o aumento do número de professores e funcionários, elencava o diretor como figura central de autoridade, versava sobre obrigações da congregação perante o Governo Imperial e dispunha sobre outros pontos do funcionamento legal das faculdades de medicina.

Muitas eram as normatizações dos Estatutos de 1854. Estes definiam as faculdades como lugares para habilitação de quem poderia praticar e ensinar a 
medicina no Império, conforme atesta o artigo $3^{\circ}$, que ajustava a duração e o currículo do curso médico, que deveria ser seguido por quem quisesse ter direito a um diploma que autorizasse oficialmente o exercício da profissão. Devemos citar, ainda, o artigo 20, que estatuía que os títulos prestados por universidades estrangeiras deveriam ser validados por uma das faculdades de medicina do Brasil. Eram os artigos 22 e 23, em adendo ao 20, que fixavam normas dos exames para validação de tais títulos.

Podemos citar, igualmente, o artigo 70 do Decreto n. 1.764 de 14 de maio de 1856, que complementava o de 1854, mas não o substituía. A cláusula, parte integrante de um capítulo dedicado a fornecer instruções sobre a colação de grau de doutor, orientava que o verso "podeis praticar e ensinar a Medicina" fosse proferido após a entrega de um anel dourado de pedra verde, completando o ciclo formal que ocorria nas faculdades e habilitava oficialmente um estudante, após seis anos de curso, à prática da profissão médica. A cerimônia significava a obtenção do diploma, da carta de autorização fornecida por uma das faculdades atestando a capacidade de alguém para ser médico e/ou prestar concursos para lecionar medicina num estabelecimento de ensino.

O regulamento de 1854 tocava na relação entre Estado e escolas de medicina. A definição de pessoal das faculdades, exigências, deveres e direitos de funcionários eram definidos, a exemplo da normativa do artigo 33, de que os diretores daquelas instituições seriam pessoas graduadas em medicina e nomeadas por decreto. A nomeação, assim, envolvia o aval do Governo Imperial. O artigo 164, parte de uma seção que falava sobre polícia acadêmica e punições, afirmava que para penas mais graves, como retenção de diplomas e perda de ano letivo, impostas pela congregação de uma faculdade a um estudante, caberia ao Estado Imperial a confirmação ou revogação da decisão tomada pelas instâncias diretoras. O artigo 17 tornava imprescindível a aprovação do Corpo Legislativo para gastos pretendidos pelas instituições de ensino. Nestes e noutros dispostos é perceptível a existência de uma estrutura 
hierárquica onde o Governo ${ }^{8}$ buscava o controle dos estabelecimentos de ensino médico.

Acreditamos que as referidas tentativas de controle se relacionavam a projetos civilizatórios de Estado, que viam na ciência um caminho para o progresso, de modo que cuidar da educação, nos moldes que faziam os governos de nações cultas, corresponderia a cuidar da própria imagem de boa administração do país. Cremos, de igual maneira, que existiam intenções de controlar ações de elites formadas por médicos, estudantes e demais envolvidos nos círculos de saber. O decreto elucidava uma hierarquia burocráticoinstitucional onde o intuito do Governo Imperial era o de permanecer no topo, o que se nota no fato de o ministro do Império ser o chefe da educação superior.

O artigo 197 do regulamento de 1854 exigia que memórias históricas sobre os principais acontecimentos e sobre a situação (ensino, estrutura física, concursos realizados, formandos, etc.,) das faculdades durante o ano letivo fossem enviadas anualmente ao Ministério do Império. Tais memórias seriam escritas por um médico-professor escolhido pela congregação de cada uma das escolas, responsável por transformar em texto tudo que aconteceu em um ano inteiro e elencar os principais problemas que precisavam de atenção. Embora nem sempre as memórias fossem fidedignas ou completas ${ }^{9}$ e que demandas nelas prescritas não fossem sempre atendidas, a existência desses textos nos serve ao propósito de pensar em algum nível de controle dos doutores nos estabelecimentos de ensino. Assuntos ausentes nas memórias, propositalmente ou não, nem sempre chegavam às vistas do Governo.

Apesar da existência de alguma autonomia sobre assuntos internos, elementos fundamentais para melhoria do ensino e, por conseguinte, da formação médica, dependiam do Estado, sobretudo em termos de organização

\footnotetext{
${ }^{8} \mathrm{O}$ conceito de "governo" pode significar várias coisas. Neste artigo, quando falamos em "governo" nos referimos à uma cúpula administrativa formada pelo poder executivo do Imperador (incluindo as diversas repartições ministeriais e outras), câmaras e outros poderes municipais, legislativo (sobretudo à assembleia legislativa), que controlavam o orçamento e autorizavam, sob aval do Imperador, decretos e leis- dentre as quais se incluem as relativas às profissões no Império do Brasil.

${ }^{9}$ Sobre o assunto ler: QUEIROZ, Vanessa de Jesus. Um termômetro vivo da civilizaçãoHigiene pública e cólera-morbo na Gazeta Medica da Bahia (1866-1870). SP: Editora Dialética, 2021.
} 
institucional oficial (currículos, horas, cargos, etc.,) e recursos financeiros (para construção de laboratórios, pagamento de ordenados e outros). Ao escrever sobre a reforma de 1854, Flávio Coelho Édler afirma que:

Os gabinetes do governo não estavam dispostos a responder positivamente os reclamos dos professores da Faculdade, que insistentemente denunciavam estar o ensino sem condições mínimas de atender às exigências de qualificação profissional (ÉDLER, 2014, p.44).

A assertiva do autor, com a qual corroboramos, demonstra a existência de conflitos entre demandas dos médicos e intenções do Estado. Evidencia, juntamente, limites da regulação de 1854 na prática.

Em 1860 foi publicada, no relatório da Repartição dos Negócios do Império, a memória histórica dos acontecimentos notáveis ocorridos na Faculdade de Medicina do Rio de Janeiro durante o ano de 1859. O texto, assinado pelo Dr. Francisco Praxedes de Andrade Pertence ${ }^{10}$, lente de anatomia geral e patologia, atendia à obrigatoriedade exigida no artigo 197 dos Estatutos de 1854. Logo no início do escrito, O Dr. Andrade Pertence relatava um dos principais problemas da Faculdade de Medicina da Corte em 1859: a escassez de candidatos aos concursos para opositores ${ }^{11}$ naquele estabelecimento. $\mathrm{O}$ memorialista destacava o fato de que certos concursos, como o que concedia a vaga de opositor da cadeira de ciências acessórias, estavam abertos há mais de um ano sem nenhuma inscrição ao cargo. Outros, para vagas de opositores das seções médica e cirúrgica, tinham preenchidas apenas 2 , de 8 vagas disponíveis. Nos internatos do hospital, onde alunos realizariam a parte prática de seus cursos, a apatia e a indiferença à candidatura também vigoravam.

Andrade Pertence (1860, pp.1-7) apresentava três causas principais para explicar tal falha. Uma delas era a insuficiência dos meios de instrução. Os laboratórios previstos pelo decreto de 1854 não haviam sido todos criados e nos que existiam eram parcos os instrumentos e número de professores disponíveis ao ensino. O doutor lamentava a notória disparidade entre a situação das escolas e dos laboratórios no Brasil e na Europa, onde as coisas estariam melhor

\footnotetext{
${ }^{10}$ Rio de Janeiro, 1836-1886.

${ }^{11}$ Classe de professores.
} 
avançadas. Outro motivo apontado era a "posição pouco feliz do opositor", diretamente prejudicada pela existência da classe de substitutos. Opositores não tinham ordenado fixo, nem dispunham da mesma contagem e respectivos benefícios provindos do tempo de serviço dos lentes. Ademais, a atuação profissional em sala de aula era instável, uma vez que professores lentes e substitutos tinham prioridade e, mediante suas presenças, a ação dos opositores em sala era preterida. A outra causa, apontada por Andrade Pertence como a principal, era a aquisição de posições por meios ilegítimos. O esculápio citava os despachos e a posição social como fatores que, não extraordinárias vezes, substituíam a honra e o merecimento nas nomeações e certificações do internato. Ele se referia aos apadrinhamentos pelos chefes de repartições governamentais que privilegiavam determinados indivíduos, causando noutros o desânimo com os concursos, uma vez que aos seus esforços se sobrepunham os vereditos de poderosos.

Favores e insuficiências eram demonstrativos substanciais de falhas na essência e na execução do regulamento de 1854 aprovado pelo Governo Imperial. A disparidade entre lei e prática nos permite perceber dificuldades enfrentadas na relação entre médicos e Estado no que concerne à administração da formação e atuação de profissionais da medicina.

Se as faculdades eram o primeiro lugar de formação e autorização, outro órgão fazia parte das possibilidades de atuação dos esculápios profissionais. Trata-se da Junta Central de Higiene Pública, repartição responsável pela fiscalização e regulação das atividades relativas à medicina no Império. Sua fundação data de 1850, quando entrou em vigor o Decreto n. 598 de 14 de setembro, que concedia ao Ministério do Império duzentos contos de réis como crédito extraordinário destinado exclusivamente a trabalhos que fizessem melhorias no estado sanitário da Capital e outras províncias do Brasil. Dentre as medidas recomendadas pelo marco legislativo, cuja existência tornou-se necessária excepcionalmente por causa das devastações da epidemia de febre 
amarela em $1849^{12}$, criou-se uma comissão de engenheiros e uma Junta de Higiene Pública. Esta foi regulada em 1851, pelo Decreto n. 828 de 29 de setembro.

O regulamento de 1851 transformou a Junta de Higiene Pública em Junta Central de Higiene Pública. O título de "central" estava relacionado a ser tal instituição autoridade, com sede na Corte, que concentraria os dados fornecidos pelos órgãos e/ou inspetores de higiene das províncias e exerceria o poder de decisão final entre eles perante o Estado, ao qual era subalterna e consultiva nas decisões de saúde pública.

$\mathrm{O}$ artigo 25, parte de um capítulo destinado a regulamentar o exercício de médicos no Império, definia que ninguém poderia exercer a medicina no Brasil sem autorização das faculdades e estabelecia multas para os transgressores de tais regras. Os artigos 26 e 27 esclareciam sobre formados em escolas estrangeiras que desejassem atuar oficial e profissionalmente no país. Ambos eram exceções à regra prevista no posterior decreto de 1854, da prestação obrigatória de exames perante as faculdades para os indivíduos que desejassem exercer a medicina no Brasil. O primeiro prescindia os exames nas faculdades, contanto que houvesse comprovação de exercício do cargo de professor de medicina, cirurgia ou farmácia em instituições reconhecidas pelo governo do país de origem. Trata-se do reconhecimento por autoridades governamentais como critério de autorização acima dos exames realizados por bancas médicas. Agentes diplomáticos do Império do Brasil ou cônsules brasileiros apareciam como figuras de poder sobre a questão. A dispensa dos exames, contudo, não escusava o indivíduo de ter de se justificar perante a uma das faculdades, o que as mantinha como lugar de autorização de exercício, conquanto em âmbito formal.

$\mathrm{O}$ artigo 27 evidenciava outro critério substituto aos exames, que era a autoria de obras conceituadas. Dizia que o Governo brasileiro, ouvidas as escolas de medicina, poderia autorizar médicos, cirurgiões e boticários

\footnotetext{
${ }^{12}$ Sobre o assunto, ver: CHALHOUB, Sidney. Posfácio a História e descrição da febre amarela epidêmica que grassou no Rio de Janeiro em 1850, de José Pereira Rego, São Paulo: Chão Editora, 2020.
} 
estrangeiros, contanto que estes fossem autores de "obras cientificas de reconhecido merecimento". O status de autor médico era, nessa perspectiva, critério para autorização e atuação. Fora os dois casos de exceção, dizia o artigo 28 do regulamento de 1851, nenhum formado em escola estrangeira poderia exercer a medicina sem a validação, pelas faculdades do Império, de seus diplomas. Esta validade ocorria a partir do reconhecimento das habilidades do candidato, via exames ou outro critério previsto, formalizada em livros de registros de matrículas que passavam pelas faculdades, autoridades municipais, incluindo as delegadas da Junta, pela Junta de Higiene Pública e finalmente chegavam ao Governo Imperial. Os artigos 34 e 35 do regulamento da Junta mencionavam a publicação de uma lista de matrículas de médicos autorizados na imprensa, para atingir o conhecimento de maior público. Tais listas serviam, ademais, ao controle por parte do Estado sobre os habilitados a praticar a medicina no Brasil.

O regulamento da Junta, que vigorou concomitante ao decreto de 1854, reforçava o poder das escolas e, simultaneamente, revelava a necessidade de validação de suas certificações pelo órgão central fiscalizador dos assuntos de medicina e higiene. Mais do que validar os diplomas concedidos pelas faculdades, à Junta cabia a função de vigiar os que exerciam a medicina sem autorização das mesmas. Aplicar penas e impedir a atuação de charlatões era parte de suas atribuições. Todavia, as ações do órgão de higiene pública apresentavam uma série de defeitos na prática.

Em meados da década de 1850, o Dr. Francisco de Paula Cândido ${ }^{13}$ explanava, em relatório da Repartição dos Negócios do Império, que à Junta Central de Higiene Pública foram incumbidas muitas responsabilidades, a exemplo da administração da Provedoria de Saúde do Porto, da Junta Vacínica, matrículas de médicos, parteiras e dentistas, fiscalização das casas de drogas e outros ramos da arte de curar. Contudo, alertava o presidente da Junta, "para o

\footnotetext{
${ }^{13}$ Minas Gerais, 1805-1864. Em 1856, ano do relatório, era médico do Imperador, primeiro secretário da Câmara dos Deputados, comendador da Imperial Ordem da Rosa, cavalheiro da de Cristo, lente da Escola de Medicina, presidente da Comissão sanitária e da Junta Central de Higiene Pública.
} 
bom desempenho de todas estas funcções não se lhe proporcionárão os indispensaveis meios" (CANDIDO, 1857, p.9). Afirmava que homeopatas e "pelotiqueiros" assombravam o país com seus conhecimentos não atestados, zombando das leis de fiscalização ou ancorando-se nas justificativas de que as desconheciam. Denunciava que "a lei fica sempre ludibriada" e que a Junta apenas podia entregar um desses charlatões à justiça ordinária "que quasi sempre os tem absolvido".

Como vemos, o poder da Junta estava limitado pela justiça ordinária, parte da burocracia estatal. O órgão central e as faculdades dialogavam de diversas maneiras, com ênfase no combate aos pelotiqueiros e charlatões. A existência das reclamações evidencia que existiam sujeitos que exerciam a arte de curar sem autorização das escolas e do próprio órgão fiscalizador. Demonstra, outrossim, a fragilidade da legislação e da autoridade da Junta, pois seus pareceres diferiam, por vezes, dos da justiça ordinária. Além do conflito entre poderes, a relação entre escolas de medicina e Junta Central é indício de que havia uma hierarquia interna ao grupo de profissionais da medicina, que tinham em comum a formação e autorização, mas nem sempre partilhavam de igual campo de atuação, pertencendo a lugares diversos, com possibilidades distintas de exercício da profissão. Um médico que trabalhava na faculdade ocupava um lugar profissional específico não igual ao daquele que trabalhava na Junta. O médico que trabalhava nos dois lugares tinha outro tipo de realidade profissional em relação aos que trabalhavam em apenas um deles. A categoria de profissional da medicina englobava variadas possibilidades de ação ${ }^{14}$.

As reclamações dos doutores Pertence e Paula Cândido são demonstrativas da assimetria entre dispositivos legais e sua aplicação prática, bem como da insuficiência de algumas leis sobre profissão médica no recorte temporal que aqui estudamos. Apesar das limitações inerentes à legislação, memórias e relatórios, a exemplo do fato de serem escritas por letrados que faziam parte de grupos específicos, deixando de fora perspectivas outras, são

\footnotetext{
${ }^{14}$ Inclusive muitos médicos escolhiam exercer funções que ultrapassavam o exercício da medicina. Lembremos dos diversos indivíduos diplomados em medicina que exerciam cargos no Senado, por exemplo.
} 
documentos profícuos para pensar as relações entre Estado e demais grupos sociais, uma vez que contêm assuntos tidos como imprescindíveis à pauta de organização e controle estatal e elucidam, ainda que a nível formal e parcial, vários dos assuntos que ocupavam as esferas política, econômica e sociocultural dos períodos de sua vigência.

No pré-guerra as faculdades se caracterizavam como importantes lugares de formação e atuação de médicos profissionais. Tais estabelecimentos de ensino eram tanto responsáveis pela formação de doutores, quanto possibilitadores de exercício da profissão daqueles que escolhiam a docência das ciências médicas como ofício. Formandos e diplomados se relacionavam de formas plurais com o Governo Imperial. Autorização para concursos, pagamento de ordenados, orçamentos para melhoria estrutural e outros pontos vitais do funcionamento das escolas de medicina dependiam do apoio governamental, cujas prioridades nem sempre coincidiam com aquelas definidas pelas congregações das faculdades. Este panorama conflituoso de visões sobre a administração dos assuntos de saúde é parte da explicação para o funcionamento insuficiente da Junta Central de Higiene Pública, que não raras vezes conflitava com outras autoridades estatais, sobretudo quanto à necessidade de maior apoio do Estado para que a fiscalização da saúde pública fosse melhor viabilizada.

Os problemas de estrutura afetavam diretamente a qualidade do ensino, muitas vezes taxado de majoritariamente teórico e deficiente na prática clínica, principalmente por causa da escassez de laboratórios, recursos e professores. As insuficiências acompanharam a passagem da década. Três anos antes da eclosão do conflito do Paraguai a situação perdurava. Na memória histórica da Faculdade de Medicina da Bahia do ano de 1861, publicada no relatório da Repartição dos Negócios do Império, o Dr. Francisco Rodrigues da Silva (1862, p.28) dizia que "na faculdade de medicina da Bahia não existe ensino pratico". O panorama do ensino majoritariamente teórico era agravado por um problema bem descrito por Carlos Bahiense da Silva $\left(2012\right.$, p.37) ${ }^{15}$ em tese sobre o Corpo

\footnotetext{
${ }^{15}$ Em tese que fortuitamente em breve se tornará livro.
} 
de Saúde do Exército: o desprezo pelo trabalho manual por parte de elites médicas. Para o autor, fração substancial do dito desprezo ocorria devido à correlação entre trabalho pesado e escravidão. Poucos anos depois, a Guerra Guasú $^{16}$ exigiria novas posturas, de rapidez e muita labuta manual, devido à necessidade de atendimento a um grande número de feridos e doentes em território hostil. Essas novas posturas foram responsáveis por uma nova forma de pensar classe médica que ascendeu junto à contenda.

Conforme aponta o mesmo autor (SILVA, 2012, p.151), o conflito se tornaria laboratório sem igual, inclusive para a convivência com a cólera. Quais os dilemas enfrentados pelos profissionais da medicina na Guerra do Paraguai? Muitos. No tópico a seguir, veremos alguns que nos ajudarão a refletir sobre a ideia de profissão médica durante a batalha.

\section{Profissão médica, Guerra do Paraguai e cólera-morbo ${ }^{17}$}

\section{Sangue no campo da honra ${ }^{18}:$ médicos na campanha}

[...] Não obstante o mao estado de mtos dos doentes, a maior parte delles apresentam melhoras consideraveis, devidas aos cuidados assiduos do academico Paiva e Angelo, ajudante do Dr. Oliveira Botelho, e dos enfermeiros Salustiano Jose Monteiro de Barros, cabos Jose Maria de Resende e Laurindo Ferreira Machado, desenvolvendo o academico grande aptidão, actividade e conhecimentos praticos e os enfermeiros mta caridade e pericia em sua profissão[...] (CORREIA, 06/08/1866)

A transcrição é parte de um ofício de seis páginas que informa sobre a situação de doentes transferidos de um hospital flutuante de Corrientes para os hospitais de Buenos Aires e Montevidéu. O documento foi enviado para um

\footnotetext{
${ }^{16}$ Outro nome para a Guerra do Paraguai.

17 Parte das reflexões fornecidas neste tópico são melhor aprofundadas em livro de nossa autoria. Ver: QUEIROZ, Vanessa de Jesus. Um termômetro vivo da civilização- Higiene pública e cólera-morbo na Gazeta Medica da Bahia (1866-1870). SP: Editora Dialética, 2021.

${ }^{18}$ Na página 13 do n.2, do ano I, da Gazeta Medica da Bahia, datado de 10 de julho de 1866, foi publicada matéria intitulada "Partida de médicos para o exército". No texto, não assinado, é dito que os médicos, sem partido que não o dos socorros da pátria, derramavam por ela seu próprio sangue no campo da honra, expondo suas vidas "em regiões inhospitas, aos perigos e calamidades inseparáveis da Guerra".
} 
ministro da guerra brasileiro pelo doutor Joaquim Antônio de Oliveira Botelho, $1^{\mathrm{o}}$ médico do hospital flutuante estabelecido a bordo do vapor Eponina. Botelho relatava o grande número de mortes por amputação, prestando destaque a alguns doentes que haviam sumido das enfermarias e acabariam por perecer devido à falta de cirurgia de ablação. O oficio elogiava a eficiência do Capitão Ataliba Manoel Fernandes, diretor do hospital flutuante mencionado, e do capelão Americo Augusto de Carvalhal Coelho dos Santos, que ajudava na cura do espírito e oferecia bons serviços como farmacêutico prático. O médico autor do escrito falava sobre o número de inválidos a bordo, operações realizadas, dietas e alguns outros assuntos.

Com os devidos cuidados metodológicos, que devem ser inerentes aos argumentos que analisam um panorama geral a partir de um caso (característica da micro-história), cremos que a figura de Joaquim Botelho nos sirva para pensar sobre atuação de médicos profissionais na Guerra para além de seu caso. O ofício nos fornece uma série de indícios sobre a vivência médica na batalha. $\mathrm{O} 1^{\circ}$ médico do vapor trabalhava em um hospital flutuante. Dos principais tipos de hospitais da campanha - permanentes, temporários e flutuantes ${ }^{19}$-, os últimos eram os mais próximos ao conflito imediato, alocados "logo atrás da linha de fogo" (MOURA, 2015, p.133). Nestes nosocômios costumavam prestar os primeiros socorros e depois transferiam os doentes para outros. Assim como os temporários, seguiam o movimento dos batalhões.

A responsabilidade de atendimentos a feridos e doentes era gigantesca nos vários tipos de hospital, porém prestar os primeiros socorros era decisivo à boa saúde das tropas e manutenção do contingente. Exercia-se a medicina de formas variadas de acordo as necessidades de cada tipo de nosocômio. A transferência para os demais hospitais é evidência de uma rede que envolvia as administrações destes estabelecimentos entre si e em relação com o Ministério da Guerra e, por conseguinte, com o Governo. Informar a situação da higiene,

\footnotetext{
19 Os hospitais permanentes eram hospitais militares construídos em localidades de maior contingente, que funcionavam em tempos de contenda e de paz, em locais fixos; os temporários, montados para os tempos de guerra, podiam funcionar em terrenos como casas, igrejas, etc., e se moviam conforme o movimento das tropas em terra firme. Os flutuantes seguiam a lógica dos temporários, contudo, costumavam estar nos mares, não em terra firme.
} 
dos médicos e dos postos de saúde respondendo e/ou enviando ofícios, era tarefa adicional à arte da cura dos esculápios diplomados que estavam em campo de batalha. A burocracia, outrossim, chegou às linhas do confronto.

A existência de doentes sumidos é indicativa do medo que alguns alimentavam quanto a se tornarem inválidos ${ }^{20}$. A fuga e o sumiço eram formas de evitar a morte, visto que os hospitais de campanha, improvisados e muitas vezes estabelecidos em prédios ou navios higienicamente inadequados, se tornavam "espetáculos de dor e agonia" e muitos soldados ocultavam seu estado de saúde para não serem levados para tais locais (BAHIENSE, 2012, pp.79-80). Parte deste receio pode ser justificada pela falta de confiança nos médicos que realizavam os procedimentos. O grande número de óbitos por amputação era outro agravante da situação. Uma forma de confortar os feridos e doentes nos hospitais estava na presença do capelão, responsável por ajudar espiritual e emocionalmente os pacientes. O cuidado espiritual era fundamental.

O documento não nos conta sobre uma formação médica do capelão, mas nos informa que ele exercia a função de farmacêutico prático. Isto pode tanto significar que, no contexto de instabilidades da Guerra, cargos geralmente exercidos por especialistas de uma área eram exercidos por pessoas não habilitadas, quanto que o capelão fosse também um farmacêutico exercendo mais de uma função. De todo modo, nos cabe refletir que médicos profissionais diplomados dividiam lugar com outros sujeitos no que tange aos cuidados e restabelecimento da saúde. O Decreto n. 1.900 de 07 de março de 1857, que regulava o Corpo de Saúde do Exército, definia que se o serviço médico seria feito por doutores habilitados em medicina (art. $1^{\circ}$ ), o de enfermeiros poderia ser feito por pessoas não necessariamente diplomadas, mas que soubessem ler, escrever e ter inteligência para o serviço a que se destinavam (art. 164). Indivíduos diplomados ou em vias de diplomação atuavam ao lado de não diplomados. A Guerra aproximou realidades e formas de curar distintas.

\footnotetext{
${ }^{20}$ Sobre os inválidos da pátria, ler: GOMES, Marcelo Augusto Moraes. "A espuma das províncias": um estudo sobre os Inválidos da Pátria e o Asilo dos Inválidos da Pátria na Corte (1864-1930).
} 
O trecho que destacamos contém o registro de nomes e boa avaliação dos serviços prestados. Dos enfermeiros apreciou-se a perícia e a caridade. Do ajudante do Dr. Botelho elogiou-se as muitas atividades e conhecimentos práticos adquiridos. As consideráveis melhoras, implicitamente, foram indicadas como fruto da boa atuação do $1^{\circ}$ médico, que organizava o serviço. Registrar os nomes dos doutores e demais agentes era maneira de atestar seus bons serviços perante a cúpula imperial. Boa parte dessas pessoas nutria a esperança de poder valer-se da boa recomendação para ambições, profissionais ou não, futuras.

De igual maneira, o registro de nomes era uma forma de lidar com o risco de morte constante em campo de batalha. Falar de pessoas no documento era estratégia de criação de memória sobre atuação dos médicos e parceiros de tropa. Não devemos perder de vista a possível intenção de construção ou reafirmação de laços. Elogiar o capitão, por exemplo, parece ser um caminho de apadrinhamento futuro ou uma forma de driblar conflitos num contexto onde, muitas vezes, patentes militares estavam hierarquicamente acima da autoridade dos doutores.

Por fim, é provável que o escritor do ofício tenha utilizado o artefato do registro de nomes para contar com testemunhas de sua própria atuação, que desejava perpetuar como satisfatória. As maneiras de escrever um documento são dotadas de intencionalidades, portanto cremos que as poucas linhas falando sobre os problemas (alta mortalidade por amputação, doentes sumidos, etc.,) e muitas destacando as conquistas (enfermeiros caridosos, bom serviço médico, alta taxa de melhoras) foi uma estrutura textual propositalmente articulada.

A presença de um acadêmico no teatro da Guerra, descrita no ofício, não era caso isolado. No n.2 da Gazeta Medica da Bahia, um artigo destacava o heroísmo da partida de médicos, docentes e estudantes de medicina da Bahia rumo ao campo da contenda. O longo texto enfatizava que o Governo Imperial não contou em vão com a corporação médica da Bahia, com "a academica especialmente", e que os que partiram voluntariamente para a batalha só reconheciam "uma nação universal - a humanidade; um partido apenas - o dos 
que soffrem" (GAZETA MEDICA DA BAHIA, 25/07/1866, p.13). Joaquim Botelho é um dos nomes mencionados pelo editorial que glorificava a ida dos médicos e estudantes para a Guerra do Paraguai.

O texto da edição n.2 sublinhava que, antes da Guerra, lutas difíceis foram enfrentadas pela corporação médica. Esses anteriores "tempos lutuosos" foram as epidemias de febre amarela em 1849 e de cólera-morbo em 1855. A honra da partida de médicos e estudantes, que largavam o conforto de suas casas temporariamente para se arriscarem em nome da nação, era parte central do argumento de que a corporação médica (que incluía diplomados e estudantes em formação) era deveras útil e leal à nação. $O$ destaque a não adoção de partidos parece ser uma referência a brigas políticas que ocorriam no contexto das esferas burocráticas. Era, também, tentativa de construção de afirmação sobre missão humanitária. A ideia era afirmar que os filhos de Hipócrates estavam acima dessas questões, o que tornaria seu papel social tanto mais louvável.

Ponderar sobre a matéria da Gazeta Medica da Bahia exige pensarmos em sua lógica de existência e produção. Vanessa Queiroz (2021) aponta para o periódico como um lugar onde demandas, fossem políticas, fossem científicas ou de outra ordem, que passassem pelo crivo da associação de facultativos que sustentava o jornal, poderiam ser expostas em suas folhas, destinadas aos escritos de medicina e discussões relacionadas. A historiadora apresenta a folha médica como parte de uma luta por legitimação, reconhecimento, autoridade e exclusividade dos médicos envolvidos com a publicação, que ora dialogava, ora conflitava com a imprensa não-médica. Entretanto, o principal ponto da autora que desejamos destacar aqui, se refere à relação dual entre a Gazeta Medica da Bahia e a Faculdade de Medicina da Bahia. Queiroz (2021) afirma que o grupo de facultativos que sustentava a Gazeta se autoproclamava, à época de seu lançamento, não vinculado oficialmente à Faculdade, apesar de contar com alguns de seus membros (alunos e professores que mandavam suas colaborações escritas e parte dos facultativos que sustentavam o jornal). 
O editorial sobre a partida de médicos elucida a dualidade apontada por Queiroz (2021). À medida que o jornal aparecia como uma plataforma alternativa, mais rápida e com capacidade de atingir um número maior de pessoas do que as teses, opúsculos e memórias históricas produzidas na faculdade, era, igualmente, lugar de afirmação da importância da corporação médica profissional da Bahia, que incluía os sujeitos da escola de medicina. Mesmo que nem todos os esculápios da faculdade apoiassem ou participassem da Gazeta, o periódico mencionava a instituição em nome de um propósito maior de afirmação da necessidade e honra de uma classe médica profissional. No periódico, proclamado como parte de uma imprensa médica em ascensão, a Guerra do Paraguai era estrategicamente utilizada como maneira de destacar a utilidade dos doutores profissionais, e em caminhos de profissionalização, aos bons futuros da nação.

A Gazeta Medica da Bahia, lugar de saber que ultrapassava as faculdades ao mesmo tempo em que delas falava muitas vezes, contém mais escritos sobre a cólera durante os primeiros anos da Guerra, do que as teses defendidas nas duas faculdades de medicina do Império para o mesmo período. Devemos ponderar que o confronto causou atrasos de produção, tendo em vista a debilitação das escolas de medicina pela partida de médicos e estudantes aos campos de batalha. Ademais, que parte dos estudos aprofundados sobre o episódio bélico só seria escrita após o seu final. A campanha afetou a formação e a atuação de esculápios em diferentes proporções e perspectivas. Foi momento oportuno para tornar demandas profissionais evidentes, a exemplo do ensino prático, no qual o contexto de contenda mostrara ser necessário investir, visto que tal campo poderia ser profícuo para que estudantes e professores estivessem mais bem preparados para tempos não pacíficos. $\mathrm{O}$ apontamento de Carlos Bahiense (2012), sobre o confronto ter sido lugar de aquisição de experiência e produção de conhecimentos sem igual, mostra o outro lado da moeda, em que o conflito se tornou o laboratório prático de muitos alunos e professores que tinham maior contato com ensino majoritariamente teórico até ali. 
A Gazeta Medica e uma série de outros jornais do período estavam inteirados de ocorrências da Guerra do Paraguai. Um tema-chave do jornal durante o confronto era o combate ao charlatanismo. Para os médicos daquele periódico, charlatões eram curadores, diplomados ou não, que destoavam da ciência, métodos clínicos (alopatas) e posturas morais por eles defendidas. Em 1870, um doutor que assinava seus textos como "L", reclamava da fragilidade das leis e da fiscalização a cargo da Junta Central de Higiene Pública. O autor deplorava a promoção de um curandeiro ao cargo de cirurgião-mor da Guarda Nacional. "L" dizia que as leis não favoreciam os verdadeiros médicos e isto fez com que vários não diplomados fossem para a campanha exercer a arte da cura. O maior prejuízo, segundo o autor, estava no fato de que tais indivíduos exerciam os serviços com direitos iguais aos dos facultativos, o que era ruim às estatísticas que mensuravam a eficácia dos tratamentos prestados e, consequentemente, para a boa imagem do serviço médico da Guerra. As reclamações de "L" elucidam que esse tipo de brecha na lei, autorizada pelo Governo Imperial, resultava num panorama onde a Junta não poderia punir alguém oficialmente vinculado e autorizado por lei da Guarda Nacional (GAZETA MEDICA DA BAHIA, 15/02/1870, pp.145-148).

$\mathrm{Na}$ Gazeta foram publicados mapas estatísticos de mortalidade e registros do serviço médico, assim como outras matérias, frutos da correspondência com doutores no campo de batalha. Outros jornais brasileiros da década de 1860 também estavam interessados e publicavam notícias sobre a cólera-morbo e a importância de prevenção à tal enfermidade, que assolava os campos de batalha e poderia chegar ao solo brasileiro. Em continuidade à nossa análise, sobre as relações entre cólera e médicos na Guerra, vejamos algumas aparições do mal colérico.

O "inimigo invisível" sob as vistas de todos: Cólera-morbo, esculápios brasileiros e Guerra do Paraguai

Na década de 1880, o médico alemão Robert Koch consolidava suas descobertas sobre a Vibrio Cholerae, bactéria causadora da cólera-morbo. O 
momento foi esclarecedor de debates que pululavam nas penas médicas de vários lugares do mundo já há algumas décadas. No Brasil, datam do século XIX as discussões enfáticas acerca da moléstia, que passou a ganhar especial centralidade quando invadiu as terras brasileiras entre 1855-1856 e se tornou premência de médicos e Estado Imperial. A epidemia cessou em 1856, legando ao país uma experiência de desespero onde várias vidas foram ceifadas. Ainda que muitos doutores tenham atuado heroicamente na frente de luta contra o mal colérico, não foi possível chegar a um consenso sobre agente causador e tratamento adequado. Contagionistas e infeccionistas ${ }^{21}$ expunham diversas teorias que não se comprovavam, nem se excluíam plenamente.

A falta de consenso perdurou na década seguinte, em que o Brasil estava livre de um novo surto nos moldes do de 1855-1856, mas era ameaçado pela chegada da doença pelos portos, uma vez que a cólera grassou com gravidade nos campos da Guerra do Paraguai em meados dos anos de sua ocorrência. Combatentes e médicos lidavam com uma poderosa inimiga, que se verteu em grave preocupação em campo de batalha devido a seu potencial debilitador e destruidor de forças, que poderia ultrapassar as fronteiras e atingir o restante do território brasileiro, sob regência de um Estado já social e economicamente abalado pelas instabilidades do conflito.

Não tão raras são as obras que versam sobre a cólera na historiografia brasileira. Boa parte delas ocupa-se de sua ocorrência epidêmica no Brasil entre 1855-1856, a exemplo do artigo de Tânia Salgado, Kaori Kodama, Francisco Bastos e Jaime Bellido (2012), em que apresentam o perfil social demográfico das mortes registradas no Rio de Janeiro durante a epidemia. No texto, que aparece como alternativa a uma historiografia tradicional não preocupada em conceder lugar central aos escravos nas análises do processo de medicalização da sociedade oitocentista, os autores informam que a moléstia ceifou mais escravos do que não-escravos. Apontam, também, que é importante pensar no

\footnotetext{
${ }^{21}$ Grosso modo, contagionistas eram os que acreditavam na transmissão da doença de pessoa para pessoa ou de objetos de um doente para um não doente; infeccionistas eram os que acreditavam que a doença era transmitida pelo ambiente - miasmas, ares pútridos, águas sujas, etc., Não raras eram as correntes de pensamento de amalgamavam as duas.
} 
surto colérico de 1855-1856 em conjunto com o de febre amarela ocorrido em 1849-1850, visto que os serviços de combate a ambos foram parecidos e foi a partir do mal amarílico que teve início uma nova perspectiva perante as epidemias. Estas passaram a ser vistas como parte da realidade do país, chamando mais atenção do Estado para a saúde e a higiene públicas.

Outro texto é de autoria de Sebastião Pimentel Franco (2014), em que encontramos o argumento de que o momento epidêmico foi causador de descrédito nas ciências médicas e seus representantes, dado o contexto de pânico e terror, onde a alta mortalidade ${ }^{22}$ causada pela enfermidade e o desconhecimento sobre causas e tratamentos eram responsáveis por uma situação instável. O artigo do autor capixaba elucida o empecilho que a doença trazia à consolidação da legitimidade e reconhecimento dos médicos diplomados, a partir da ausência de soluções que se esperava que tivessem quanto à cólera.

Outro trabalho referência sobre a epidemia encontra-se na obra de Onildo Reis David (1996). Ao analisar o contexto baiano na chegada da doença, polícia sanitária, reação popular e crise do comércio e alimentação durante o surto, David demonstra que a cólera transformou várias características da vida social, a exemplo da crença, da religiosidade, das expectativas quanto às funções de médicos e Governo Imperial. O autor aponta o fracasso das ações de saúde pública promovidas por Estado e grupos médicos, enquanto enfatiza as ações heroicas de alguns esculápios para os quais a epidemia foi momento de busca por reconhecimento e oportunidade de descobertas. O texto evidencia o conflito interno ocorrido a partir das muitas posturas de médicos perante a moléstia, num contexto onde alguns enfrentavam-na e outros literalmente fugiam e abandonavam seus cargos. David nos conta sobre problemas apresentados à autoridade dos doutores diplomados, a exemplo da grande presença das crenças religiosas para explicar a cólera e da constante pressão das

\footnotetext{
${ }^{22}$ E Franco corrobora com os dados de Salgado et al (2012) sobre a maior mortalidade escrava também no Espirito Santo.
} 
matérias publicadas na imprensa que, junto à informação, espalhavam alto nível de preocupação pública.

As obras até aqui mencionadas comprovam a especial atenção que deve ser concedida à epidemia de 1855-1856, por nós vista como potencializadora da seriedade que a cólera ganhava perante os médicos no teatro da Guerra do Paraguai. Em 1866, José de Goés Sequeira alertava para a necessidade de os médicos estarem preparados e não se mostrarem vacilantes "se tivermos a infelicidade de travar segunda lucta com o medonho flagello" (GAZETA MEDICA DA BAHIA, 10/10/1866, p.74). A primeira luta teria ocorrido em 1855-1856. Não seria profícuo ao reconhecimento dos médicos profissionais uma nova epidemia em território nacional, que poderia ser ainda mais prejudicial aos esculápios diplomados devido ao contexto já instável pela contenda do Paraguai. Em 1855-1856, a guerra era contra a epidemia de cólera. Na década de 1860, caso se repetisse, se somaria aos males de uma outra guerra em andamento.

Casos isolados da doença apareceram nos relatórios da Repartição dos Negócios do Império dos anos de 1857, 1861 e 1862, porém sem a gravidade manifestada entre 1855 e 1856, onde o caos invadira ao mesmo tempo muitas províncias do Brasil. Dois casos de cólera que ocorreram em 1853 foram citados no relatório dos Negócios do Império de 1855, antes da epidemia do Brasil que era, em verdade, parte de uma pandemia de cólera que afetava vários países do mundo. Parte da historiografia brasileira sobre o assunto destaca o despreparo de médicos e administração imperial para lidar com a moléstia. Sem embargo, é importante analisar tais considerações com cuidado. O despreparo não corresponde à uma surpresa total perante a chegada da doença a solos brasileiros. Em 1854, Luiz Pedreira do Couto Ferraz, ministro do Império naquele ano, falava sobre algumas medidas preventivas tomadas por um presidente de comissão sanitária e pela direção do Hospital Marítimo de Santa Isabel, devido aos receios do Governo quanto à importação da febre amarela e da cólera-morbo. 
Muito embora nem todas as medidas tenham sido eficazes, não se tenha chegado a um consenso quanto a causas e o caos tenha sido realidade em 18551856, o risco de o Brasil ser atacado pelo mal colérico, visto que ele grassava em outros países com que se mantinha relações comerciais e culturais, era considerado pelo Estado Imperial, conforme nos conta o mesmo ministro no relatório de 1855, onde afirmava que a biblioteca da Academia Imperial de Medicina havia se enriquecido, com destaque a obras que versavam sobre a epidemia reinante (de cólera), pois o Governo, ressentido da possível eclosão, já as havia encomendado (FERRAZ, 1855, pp. 65-66).

Já pensando nas doenças in Guerra do Paraguai, o tema chamou a atenção de alguns pesquisadores e pesquisadoras brasileiras, se caracterizando como elementos centrais de suas considerações. A título de exemplo, podemos citar a obra de Janyne Barbosa - Uma guerra sangrenta epidêmica e doente (2018), onde a autora focaliza suas análises no cotidiano de civis e enfermos, bem como nas práticas médicas, concedendo especial lugar às doenças e espaços de cura por estas impulsionados e/ou justificados. Médicos, práticos, hospitais, transportes de doentes, a cólera, a varíola e outros males são alguns dos eixos abordados em seu texto. Podemos mencionar, também, a dissertação de Maria Teresa Garritano Dourado (2010), preocupada com as doenças, fomes e penalidades no confronto. A autora apresenta as doenças e a fome como fatores diretamente relacionados à imposição de penalidades diversas e, também, como elementos cruciais nas considerações sobre os resultados do conflito.

A já citada tese de Carlos Bahiense da Silva, Doutores e Canhões... (2012), é importante diálogo para pesquisas interessadas nas relações entre medicina e guerra. Se divide em três eixos principais: O Corpo de Saúde do Exército, a epidemia de cólera e a cirurgia em campanha. O escrito problematiza questões da repartição de saúde do exército, a exemplo do fato da chefia médica não ser exercida por médicos. Além disso, versa sobre a cólera e cirurgia no confronto, apontando ser o campo de batalha laboratório para aquisição de conhecimentos. $\mathrm{O}$ autor apresenta, junto a algumas dificuldades 
enfrentadas, a exemplo dos estudantes atuantes em campo de batalha, que eram dotados de muita teoria e pouca prática, o que complicava o serviço médico de guerra (BAHIENSE, 2012, p.57), o fato de que o confronto aumentou a necessidade de doutores atuantes. Acreditamos que este aumento foi aproveitado pelos esculápios como lugar de exposição de demandas e estratégias relativas à valorização do médico diplomado profissional.

Aureliano de Moura é outro nome que centraliza as doenças como justificativas para suas considerações sobre a atuação do Corpo de Saúde do Exército... (2015). Em sua narrativa percorre as batalhas que compõem o confronto enfatizando ações, problemas sanitários e doenças enfrentadas. Explica que não obstante o Exército estivesse mal organizado (baixo contingente, ausência de preparo, etc.,), por não ser uma prioridade do Império desde antes da Guerra, os médicos e boticários do Corpo de Saúde não eram incompetentes e insuficientes. $\mathrm{O}$ autor ressalta a disparidade entre número de pacientes e doutores disponíveis, assim como a falta de recursos para auxiliar feridos e enfermos. Obras clássicas como Maldita Guerra (2002), de Francisco Doratioto, também concedem papel central a doenças como a varíola e a cóleramorbo.

A lista de obras que analisam as doenças na conflagração é mais longa do que a que expusemos. Contudo, cremos que o breve balanço historiográfico seja útil tanto para nos ajudar a compreender a relação entre ocorrência de doenças e legitimação/ reconhecimento da profissão médica, quanto para alocar o nosso próprio argumento, que considera as epidemias, com ênfase na de cólera-morbo, elementos fundamentais para pensar a figura dos médicos profissionais no confronto.

"Quem é o culpado? Será o simples e obscuro medico que por si só fez quanto cabia em suas forças para prevenir o apparecimento do mal, ou o general que escarneceu da sciencia medica e só confiou nos seus conhecimentos?" (DIARIO DO RIO DE JANEIRO, 27/09/1867, p.3). O trecho faz parte de uma carta assinada pelo Dr. Joaquim Antônio de Oliveira Botelho, à época diretor do hospital flutuante D. Francisca. Foi enviada ao Diario do Rio de Janeiro em 
resposta a um tal "escrevinhador", que o havia culpado pela chegada da cóleramorbo em Curuzú. O tal escrevinhador publicou a acusação sob o formato de carta no Jornal do Commercio (PA) de 07 de maio daquele ano, 1867. O acusador afirmava que a doença havia chegado à dita localidade devido à incúria do diretor da embarcação. Botelho retrucou oferecendo a sua versão dos acontecimentos. Explicou que tomou as adequadas medidas de higiene, dentro das possibilidades que lhe foram dadas. Avisou ao general comandante, Visconde de Porto Alegre, sobre a existência de cólera a bordo do navio e os perigos acarretados caso as medidas de prevenção indicadas não fossem aplicadas. Segundo o doutor, suas recomendações foram ignoradas pelo general por considerável tempo.

O trecho nos permite algumas considerações. A primeira é sobre a imprensa como lugar de informação e palco de debates sobre acontecimentos do conflito. A segunda é que a acusação do escrevinhador mostra uma das imagens esperadas do profissional da medicina: a de pessoa que, além de cuidar de feridos e doentes, evitasse que as enfermidades invadissem um território. Porém, não devemos descartar a possibilidade de o escrevinhador ser um inimigo de Botelho, que ia contra suas teorias e posicionamentos e usou o episódio para ferir-lhe a reputação. A terceira refere-se à hierarquia entre médicos e não médicos, expressa no fato de o Visconde de Porto Alegre ter ignorado as recomendações do esculápio. Trata-se do argumento de que os serviços médicos precisavam do apoio de outras instâncias de autoridade. Por fim, percebemos que a cólera era assunto de muitos, visto que transcendia o campo de batalha e invadia as folhas da imprensa. Alguns casos de cólera foram registrados em algumas províncias durante alguns anos da Guerra, mas a doença não atingiu caráter epidêmico como em 1855-1856. Porém, cremos que a experiência anterior, somada à ausência da descoberta sobre agente causador e tratamentos certeiros, colaborou para a ameaça da cólera tornar-se um "inimigo invisível"23 - pois não se sabia o que o causava-, sob as vistas de todos.

\footnotetext{
${ }^{23}$ A expressão aparece em: Gazeta Medica da Bahia, ano I, n.4, 25 de agosto de 1866, p.38, Artigo editorial- "Não devemos receiar a importação da cholera-morbus?", onde o autor, que não assina o escrito, refere-se à cólera-morbo como "inimigo invisível e traiçoeiro".
} 
Em 1869, o Jornal do Commercio (RJ) publicava um texto intitulado "Estudantes de Medicina na Guerra do Paraguai” (JORNAL DO COMMERCIO RJ, 11/12/1869, p.1). O escrito apontava a importância de não deixar ao esquecimento a participação de nomes que mereciam o galardão da lembrança devido à boa atuação durante o conflito. $\mathrm{O}$ autor afirmava que diversos estudantes não pouparam esforços para ajudar a nação, mesmo perante as condições adversas e precárias de muitos postos de saúde, muitas vezes flagelados pelas epidemias. Dizia que nas intempéries do confronto, quando estava a existência "prestes a extinguir-se nas ondas do sangue que espadana da artéria aberta é salva pelo medico, que nessas ocasiões e em tantas outras, corre os mesmos riscos que o soldado que peleja”. Como no caso da publicação de Botelho, porém por motivação diferente, o texto publicado, talvez escrito por algum médico ou estudante de medicina, objetivava a construção de memória e verdade específicas sobre atuação de estudantes em vias de profissionalização. O trecho que reproduzimos traz a equiparação entre médico e soldado no que tange à peleja, o que indica que parte da luta por legitimação durante a ocorrência da Guerra passava pela necessidade de convencer a opinião pública de que combatentes não eram somente os que pegavam em armas. O dever dos que salvavam vidas era uma luta honrosa e garantidora das forças brasileiras em combate.

\begin{abstract}
Lemos em um jornal que um pharmaceutico homeophata do Rio de Janeiro offerecera ao governo os globulos mysteriosos para combater a cholera-morbus no exercito! É valiosissima a offerta. É sabido que os amantes do globulismo pagam caro o gosto pela medicação symbolica: tres a seis globulos por cinco mil réis é o preço das mininas cotações cá pelas provincias; quanto não valerão lá pela côrte[...] (GAZETA MEDICA DA BAHIA, 25/05/1867, pp. 263-264)
\end{abstract}

Neste texto o autor repugna a oferta, ressaltando a falta de credibilidade da homeopatia e a imoral ação de o farmacêutico homeopata oferecer um método considerado charlatão pelos alopatas, a preço exorbitante. Além da disputa pelo método adequado de cura entre os alopatas da Gazeta e o boticário homeopata, percebemos que a oferta de serviços ao Governo não era um privilégio dos primeiros. A cólera era assunto de diferentes vozes, que a 
interpretavam e utilizavam de muitas maneiras. Quando sabemos que vários homeopatas foram antes alopatas diplomados pelas faculdades de medicina do Império $^{24}$, reforça-se a consideração de que a existência dessa outra classe de curadores atesta que parte da luta por legitimação dos profissionais da medicina passava pelos conflitos internos aos diversos grupos médicos, entre os próprios diplomados. Estes não eram homogêneos.

Refutar os homeopatas que prestavam serviços ao Governo era maneira de livrar o Estado de soluções caras e ineficazes, mas também de argumentar que os serviços alopatas seriam os adequados. No caso do jornal médico baiano, lançado durante a ocorrência do conflito, esse tipo de argumento mostra mais claramente como a Guerra era utilizada pelos esculápios para exporem a fundamentabilidade de que o Estado atendesse a necessidades da profissão evidenciadas pelo episódio bélico.

De 1850 à década da Guerra do Paraguai, as demandas por melhores estruturas e possibilidades de ensino médico, assim como por apoio governamental à fiscalização dos sujeitos não diplomados, fizeram parte das imagens acerca de quem eram os doutores profissionais e quais as suas funções. Muitos grupos médicos, de professores e estudantes, encontraram no campo de batalha lugar de mostrar ao Governo Imperial sua importância como profissionais preocupados com os bons rumos da nação. Concomitantemente, os objetivos de reconhecimento, legitimidade e exclusividade profissional almejados, conflitaram com as ações de não diplomados, que de igual modo viram nos momentos de instabilidade, a exemplo da ocorrência de cólera, oportunidade para sugerirem suas demandas, estratégias e concepções.

Obstáculos não propositais, a exemplo de indivíduos como o guia Lopes, que tinha sua própria arte de combate aos problemas de saúde (as laranjas), muito presentes sobretudo em tempos de Guerra, onde a proporção entre doenças, atendimento médico e tratamentos eficazes não é equilibrada, também eram coisas com as quais os profissionais ou sujeitos em vias de

\footnotetext{
${ }^{24}$ A exemplo de José Alexandre de Mello Moraes, responsável pela publicação $O$ Medico do Povo (RJ) no ano de 1864.
} 
profissionalização atestada por diploma tinham de lidar. A atuação da Junta Central de Higiene Pública foi, de igual maneira, dificultada pela contenda, o que ficou evidente no caso da reclamação de "L" sobre a promoção de um curandeiro à cirurgião-mor.

As imprensas médica e não médica foram importantes por concederem voz a debates, informarem e formarem posicionamentos sobre as doenças e os médicos na Guerra do Paraguai. Jornais como a Gazeta Medica da Bahia forneceram dados e incitaram considerações que serviriam de base para novos conhecimentos acerca da cólera e outras questões médicas de batalha.

A Guerra Guasú por vezes potencializou problemas enfrentados por profissionais da medicina, por vezes os transformou e fez surgir novas pautas dos saberes e demandas das ciências médicas como campo profissional.

Médicos civis $\mathrm{X}$ Médicos militares? Breves reflexões sobre o conceito de classe médica: algumas considerações finais

No relatório da Repartição dos Negócios da Guerra de 1861, o Marquês de Caxias, ministro naquele ano, anunciava alterações no Regulamento do Corpo de Saúde do Exército. O Decreto n. 2.715 de 26 de dezembro de 1860, assinado pelo ministro anterior, Sebastião do Rego Barros, continha 15 artigos que mudavam as disposições do Decreto n. 1.900 de 07 de março de 1857. As principais alterações resumiam-se ao aumento de pessoal e a mudanças sobre a admissão de civis em cargos do Corpo. Os dispostos intencionavam reduzir a participação de não militares na repartição de saúde do Exército. Uma das medidas que exemplifica a assertiva é a redução (de 09 para 04) de alunos pensionistas civis admitidos para a prática clínica nos hospitais militares.

Caxias (1861, p.21) explicava que o número de segundos cirurgiões e farmacêuticos do Exército havia sido aumentado, mas ainda não preenchido. Relatava que esperava que logo o fosse para "então dispensar do serviço militar de saude todos os medicos e pharmaceuticos civis que [...] existem engajados para aquelle serviço, e que o havião sido para supprir a deficiência do Corpo de Saude". 
O documento clarifica uma configuração onde as lógicas do serviço dos profissionais médicos militares e civis eram diferentes. Ambos se formavam e tinham autorização para exercício da medicina nas faculdades de medicina do Império. Contudo, seus lugares de atuação esperados variavam. Ambas as categorias podiam praticar e ensinar a medicina, mas em caso de pertencimento ao Exército, a partir do ingresso no Corpo de Saúde, o médico profissional passava a obedecer a lógicas que transcendiam a repartição de saúde e seguiam a hierarquia da própria instituição, o Exército, majoritariamente voltada ao atendimento de praças e corpos pertencentes ao serviço militar.

Na Guerra do Paraguai, esses planos de segregação entre os dois tipos profissionais foram em parte ofuscados. Médicos civis e militares conviveram mais intensamente, o que deu ensejo a diálogos e conflitos entre ambos, chamou maior atenção dos civis para a necessidade de estudos sobre a medicina militar e acarretou uma série de consequências para a relação entre os dois tipos de médico profissional, que antes do confronto eram algo separados por ambientes de trabalho, sobretudo nos hospitais civis e nos militares, mas na Guerra tiveram a convivência estreitada. Uma análise esmiuçada acerca desta questão exigiria um outro artigo específico sobre o tema. Contudo, a mesma deve ser citada para que compreendamos outra das facetas a se considerar quando pensamos na figura do médico profissional na conflagração. Os lugares de atuação e a convivência de médicos civis e médicos militares foram ressignificados durante o conflito.

Em vias de finalização do artigo, desejamos evocar os dilemas e diversidades envolvidos na medicina como profissão exercida na Guerra para lançar a seguinte pergunta: É possível, dadas as diferenças entre os grupos médicos - civis, militares, professores, clínicos, membros da Junta, membros de jornal médico, não membros de jornais médicos, etc.,-- sustentar o conceito de classe médica? Partimos da categoria histórica como proposta por Queiroz (2018), que define:

A Classe médica refere-se a sujeitos diplomados por uma faculdade de medicina (do Brasil ou de fora do país, contanto que tais diplomas fossem reconhecidos por autoridades 
brasileiras) que exerciam o ofício de professores e/ou pesquisadores e/ou médicos em faculdades, hospitais, clínicas e atendimentos particulares. Também englobava estudantes de medicina (ainda não diplomados, mas legitimados por serem alunos de uma instituição), bem como especialistas em Farmácia e Cirurgia. Os membros desta classe partilhavam de meios e recursos em comum, a exemplo dos regulamentos dos estabelecimentos onde trabalhavam e licença para exercício da profissão que exerciam. Mas há, também, no seio do que se chama de classe médica, divergências teóricas e políticas que tornam perigosa a ideia de "classe" que, se não ponderada cuidadosamente, pode tornar uno o que é heterogêneo (QUEIROZ, 2018, p.110)

Ao falar sobre a formação da classe operária inglesa, o historiador Edward Thompson (1987) aponta a noção de classe como fenômeno histórico, de modo que análises sobre ela devem considerar a ação de pessoas e suas experiências em relação com o contexto, bem como a articulação de interesses em comum. As ideias do autor são deveras mais amplas do que as poucas linhas que utilizamos para falar do complexo conceito. Ademais, Thompson está preocupado em explicar uma outra tipologia, exemplificada no caso de outro país, noutro contexto. Porém, trazemos sua ponderação para enfatizar a prudência de pensar classe como grupo que partilha interesses, dilemas e conflitos entre si, a partir de suas experiências, num determinado contexto. Os médicos profissionais das décadas de 1850 e 1860 partilhavam a formação, algumas ideias e interesses em comum- a exemplo do enfretamento ao charlatanismo e das dificuldades no campo de batalha. Entretanto, sob o rótulo de médico profissional estavam sujeitos das mais diversas posições, ações e experiências acerca da profissão médica, resultantes de diferentes lugares que ocupavam na sociedade da segunda metade do século XIX.

Acreditamos que a definição proposta por Queiroz (2018) pode sim ser utilizada, contanto que sejam tomados alguns cuidados- e a própria autora afirma se tratar de conceito perigoso. Tais precauções referem-se a explicar, contextualizar e assumir diferenças englobadas pelo conceito. Falar em médicos civis, militares, que publicavam nos jornais, que não publicavam, que atuavam ou não nas faculdades e na Junta é falar sobre pluralidades. Esses 
distintos tipos profissionais coexistiam, se transformavam, por vezes dialogavam, por vezes conflitavam. Mas carregavam em comum o rótulo de médicos.

O movimento de transformar ações de grupos médicos em algo explicado pela categoria histórica de classe médica passa pelo caminho de considerar que um conceito não é algo que anula diversidades, mas antes serve para melhor organizar explicações e narrar relações entre pessoas, instituições, símbolos e a forma como se comunicam, se enxergam, se interpretam. Definir diferentes sujeitos como uma classe é um exercício metodológico, obedece a critérios explicativos relativos à própria maneira de se escrever História e tornar argumentos inteligíveis.

Quando Joaquim Botelho foi acusado pela chegada da cólera em Curuzú, sua defesa foi por um lado uma autodefesa direta de sua própria pessoa, por outro a denúncia de casos onde confrontos de autoridades resultavam no descrédito a todos os médicos diplomados, que precisavam de autoridade e respeito em campo de batalha. Quando "L" criticava a promoção do curandeiro, evocava um problema não só dele, mas os prejuízos à classe profissional a que pertencia. Quando o autor do editorial sobre a partida de médicos para o Exército ressaltava a importância dos filhos de Hipócrates em auxílio ao Governo para a soberania da nação, usou o termo "corporação médica". A ideia de classe médica pode ser aplicada àqueles que atuavam legitimados por um diploma ou por sua futura aquisição e eram, sob o elemento comum dos assuntos de doença e cura, alocados na categoria de médico profissional. Apesar das diferentes atitudes e posicionamentos destes profissionais, as conquistas (ou ausência delas) de um grupo médico específico poderiam surtir efeitos na reputação e nas possibilidades de atuação que o ultrapassavam e atingiam a outros.

\section{Referências}

BARBOSA, Janyne Pereira de Paula Leite. Uma guerra sangrenta, epidêmica e doente: espaços de cura e cotidiano médico na guerra do Paraguai (1864 - 1870). Dissertação de mestrado, UFPB, 2018. Disponível em: < 
https://repositorio.ufpb.br/jspui/bitstream/123456789/11899/1/Arquivototal.pdf >. Acesso em novembro de 2020.

BRASIL. Decreto $n^{0} 828$ de 29 de setembro de 1851. Manda executar o regulamento da Junta de Hygiene Publica. Disponível em: < https://www2.camara.leg.br/legin/fed/decret/1824-1899/decreto-828-29-

setembro-1851-549825-publicacaooriginal-81781-pe.html >. Acesso em novembro de 2020.

BRASIL. Decreto $\mathbf{n}^{0} \mathbf{1 . 3 8 7}$ de 28 de abril de 1854. Dá novos Estatutos ás Escolas de Medicina. Disponível em:< https://www2.camara.leg.br/legin/fed/decret/1824-1899/decreto-1387-28-abril1854-590272-publicacaooriginal-115439-pe.html>. Acesso em novembro de 2020.

BRASIL. Decreto $\mathbf{n}^{0} \mathbf{1 . 7 6 4}$ de 14 de maio de 1856. Dá novos Estatutos ás Escolas de Medicina. Disponível em: < https://www2.camara.leg.br/legin/fed/decret/1824-1899/decreto-1764-14-maio1856-571247-publicacaooriginal-94339-pe.html>. Acesso em novembro de 2020.

BRASIL. Decreto $\mathbf{n}^{\circ} \mathbf{1 . 9 0 0}$ de 07 de março de 1857. Approva o novo Regulamento do Corpo de Saude do Exercito. Disponível em:< https://www2.camara.leg.br/legin/fed/decret/1824-1899/decreto-1900-7-marco1857-557890-norma-pe.html>. Acesso em novembro de 2020.

BRASIL. Decreto $\mathbf{n}^{\mathbf{0}} \mathbf{2 . 7 1 5}$ de 26 de dezembro de 1860. Altera o regulamento approvado pelo Decreto n. ${ }^{\circ} 1.900$ de 7 de março de 1857. Disponível em: < https://www2.camara.leg.br/legin/fed/decret/1824-1899/decreto-2715-26-

dezembro-1860-556873-publicacaooriginal-77048-pe.html>. Acesso em novembro de 2020.

BRASIL. Relatórios da Repartição dos Negócios do Império. Anos 1854, 1855, 1857,1861 e 1862 Disponíveis em: < http://bndigital.bn.br/acervodigital/brasil-ministerio-imperio/720968> . Acesso em novembro de 2020.

CANDIDO, Francisco de Paula. Relatório sobre a saúde pública da capital do Império tratando da febre amarela, do cólera-morbo, das moléstias ordinárias e das medidas necessárias, da Junta Central de Higiene Pública, da Comissão Sanitária e dos Hospital Marítimo de Santa Isabel. In: Relatório da Repartição dos Negócios do Império referente ao ano de 1856, publicado em $1857 . \quad$ Disponível em: <http://memoria.bn.br/pdf/720968/per720968_1857_00001.pdf>. Acesso em novembro de 2020.

CAXIAS, Marquês de. Serviço Militar de Saude. In: Relatório da Repartição dos Negócios da Guerra. Tipografia Universal de Laemmert, Rio de Janeiro, 1861. Disponível em: < http://memoria.bn.br/pdf/720950/per720950_1861_00017.pdf>. Acesso em novembro de 2020. 
CORREIA, Mariano Carlos de Sousa. Ofício ao ministro da guerra informando da situação de doentes transferidos/ Transmissão de ofício remetido pelo Dr. Joaquim Antônio de Oliveira Botelho, $1^{\circ}$ médico do vapor Eponina. Rio de Janeiro, 08 de agosto de 1866, 6 páginas. In: Coleção Mário Barreto, Biblioteca Nacional, Rio de Janeiro, pasta 3404 002, n. 41.

DIARIO DO RIO DE JANEIRO, ano L, n. 252, 27 de setembro de 1867, p. 3. Publicações a pedido, por Joaquim Antônio de Oliveira Botelho. Disponível em:

$<$ http://memoria.bn.br/DocReader/docreader.aspx?bib=094170_02\&pasta=ano \%20186\&pesq=\&pagfis $=22351>$. Acesso em novembro de 2020.

DORATIOTO, Francisco Fernando Monteoliva. Maldita Guerra: nova história da Guerra do Paraguai. Paulo: Cia das Letras, 2002.

DOURADO, Maria Teresa Garritano. A história esquecida da Guerra do Paraguai: fome, doenças e penalidades. Tese de doutorado, USP, 2010. Disponível em: < https://teses.usp.br/teses/disponiveis/8/8138/tde-08122010135132/pt-br.php>. Acesso em novembro de 2020.

ÉDLER, Flávio Coelho. Ensino e profissão médica na Corte de D. Pedro II. São Paulo: Ufabc, 2014.

FRANCO, Sebastião Pimentel. Pânico e terror: a presença da cólera na Província do Espírito Santo (1855-1856). Almanack [online]. 2014, n.7, pp.117-136. Disponível em: < http://www.scielo.br/scielo.php?pid=S223646332014000100117\&script=sci_ab stract\&tlng $=\mathrm{pt}>$. Acesso em novembro de 2020.

GAZETA MEDICA DA BAHIA (fac-simile), ano I, n.2, 25 de julho de 1866, p.13/capa. Partida de medicos para o exercito, sem assinatura.

GAZETA MEDICA DA BAHIA (fac-simile)., ano I, n.6, 25 de setembro de 1866, p.66. Influencia nociva das dejecções cholericas: meios que convem empregar para neutralisar, ou evitar os seus effeitos, assinado pelo Dr. José de Goés Sequeira.

GAZETA MEDICA DA BAHIA (fac-simile),, ano I, n.22, 25 de maio de 1867, pp.263-264. Offerta Homeopathica, sem assinatura.

GAZETA MEDICA DA BAHIA (fac-simile), , ano IV, n.85, 15 de fevereiro de 1870, pp.145-148. A proposito da promoção de um curandeiro a cirurgiãomor da guarda nacional, assinado por "L."

JORNAL DO COMMERCIO (RJ), ano 48, n.343, 11 de dezembro de 1869, p. 1, segunda folha, Estudantes de Medicina na Guerra do Paraguai, sem 
assinatura.

Disponível

em: $<$

http://memoria.bn.br/DocReader/docreader.aspx ?bib=364568_05\&pasta=ano\% 20186\&

pesq $=>$. Acesso em novembro de 2020 .

KODAMA, Kaori et al. Mortalidade escrava durante a epidemia de cólera no Rio de Janeiro (1855-1856): uma análise preliminar. Hist. cienc. saudeManguinhos [online]. 2012, vol.19, suppl.1, pp.59-79. Disponível em: < http://www.scielo.br/scielo.php?script=sci_arttext\&pid=S0104

$59702012000500005 \& \operatorname{lng}=$ pt\&tlng=pt>. Acesso em novembro de 2020.

MOURA, Aureliano Pinto de. A atuação do Corpo de Saúde do Exército na Guerra da Tríplice Aliança. Disponível em:< http://www.revistanavigator.com.br/navig21/dossie/N21_dossie10.pdf >. Acesso em novembro de 2020.

PERTENCE, Francisco Praxedes de Andrade. Memória Histórica dos acontecimentos notáveis da Faculdade de Medicina do Rio de Janeiro no ano de 1859. In: Relatório da Repartição dos Negócios do Império, 1859, anexo G. Disponível em: < http://memoria.bn.br/pdf/720968/per720968_1859_00001.pdf>. Acesso em novembro de 2020.

QUEIROZ, Vanessa de Jesus. Uma luta contra o "indiferentismo": Imprensa Médica e Charlatanismo no Brasil em meados de 1860. Revista De História Da UEG, 7(2), 105-130. Disponível em: <https://www.revista.ueg.br/index.php/revistahistoria/article/view/8437>. Acesso em novembro de 2020.

QUEIROZ, Vanessa de Jesus. Um termômetro vivo da civilização- Higiene pública e cólera-morbo na Gazeta Medica da Bahia (1866-1870). São Paulo: Editora Dialética, 2021.

SILVA, Carlos Leonardo Bahiense da. Doutores e canhões: o corpo de saúde do Exército Brasileiro na Guerra do Paraguai (1864-1870). Tese de doutorado, COC Fiocruz, Rio de Janeiro, 2012. Disponível em: $<$ https://www.arca.fiocruz.br/handle/icict/17803 > Acesso em novembro de 2020 .

SILVA, Francisco Rodrigues da. Memória Histórica dos acontecimentos notáveis ocorridos no ano de 1861 na Faculdade de Medicina da Bahia. In: Relatório da Repartição dos Negócios do Império, 1862, anexo D. Disponível em: <http://memoria.bn.br/pdf/720968/per720968_1861_00001.pdf >. Acesso em novembro de 2020.

SOUZA, Luiz de Castro. A medicina na Guerra do Paraguai. Rio de Janeiro: Academia Brasileira de Medicina Militar, 1972. 
TAUNAY, Alfredo Maria Adriano d'escragnolle. A retirada da Laguna. Tipografia Americana, Rio de Janeiro, 1874. Tradução de Salvador de Mendonça. Disponível em: $<$ https://www2.senado.leg.br/bdsf/handle/id/221688>. Acesso em novembro de 2020.

THOMPSON, Edward Palmer. A formação da classe operária inglesa: a árvore da liberdade. Rio de Janeiro: Paz e Terra, 1987a. v. 1.

Recebido em: 12 de novembro de 2020 Aceito em: 8 de novembro de 2021 